\title{
Rechtspositie Badan Hukum Privat Dalam Penyelenggaraan Pemerintahan
}

\author{
A. Sakti Ramdhon Syah R. \\ Fakultas Hukum, Universitas Muhammadiyah Sorong \\ Email : Ramdhansyah44@gmail.com
}

\begin{abstract}
Abstrak
Penelitian ini bertujuan untuk menganalisis mengenai kedudukan hukum (rechtspositie) badan hukum privat dalam dalam ketatanegaraan, serta kedudukan badan hukum privat dalam penyelenggaraan pemerintahan. Tipe penelitian yang digunakan adalah penelitian hukum normatif-yuridis, yakni mengacu pada norma hukum peraturan perundang-undangan (statute approach), serta teori dan asas hukum sebagai pendukung. Penelitian ini bersifat deskriptifanalitis, dengan pendekatan kualitatif. Hasil penelitian menunjukan bahwa terdapat perbedaan secara paradigmatik antara kajian ketatanegaraan serta administrasi negara, dan kajian keperdataan mengenai konsep badan hukum. Dalam pada itu, praktik sehari-hari menunjukan bahwa badan hukum privat juga terlibat dalam proses penyelenggaraan pemerintahan, walaupun dengan batasan kewenangan tertentu (quasi). Walaupun demikian, diperlukan kajian mendasar sebab negara dalam pengertian staat in beweging memiliki ruang lingkup yang sangat luas. Hal ini dimaksudkan agar hak menguasai negara berdasarkan Pasal 33 ayat (2) dan (3) UUD NRI 1945, tidak bersifat koorporatis semata, sebab menyangkut hajat hidup orang banyak. Pembentukan peraturan perundang-undangan yang mengatur tentang badan hukum secara tersendiri merupakan salah satu opsi konstitusional.
\end{abstract}

Kata Kunci : Hukum Tata negara, Hukum Administrasi Negara, Badan Hukum.

\section{PENDAHULUAN}

Dalam tradisi negara kesejahteraan (welfare state), peran negara dalam memberikan sebanyak-banyaknya kesejahteraan kepada warga negara tidak hanya berasal dari terminologi negara kesejahteraan itu sendiri, tetapi juga sebagai wujud pelaksanaan dari konsep negara hukum modern. Pelaksanaan penyelenggaraan pemerintahan dalam rangka menyejahterakan warga negara pada prinsipnya merupakan titah utama dari konsep demokrasi yang menghendaki partisipasi rakyat dalam penyelenggaraan pemerintahan.

Negara Indonesia berdasarkan Pasal 1 ayat (2) dan (3) UUD NRI 1945, ditegaskan bahwa

kedaulatan berada di tangan rakyat dan dilaksanakan menurut Undang-Undang Dasar, serta Negara Indonesia adalah Negara hukum. Hal ini berarti bahwa penyelenggaraan pemerintahan terdapat 2 (dua) elemen penting, yaitu unsur kedaulatan rakyat dan unsur negara hukum. Tugas 
negara sebagai penyelenggara pemerintahan dalam memberikan pelayanan kepada publik pada hakikatnya dituntut untuk dilaksanakan sebaik-baiknya berdasarkan peraturan perundangundangan dan juga berdasarkan Asas-Asas Umum Penyelenggaraan Pemerintahan (AUPB) yang berangsur-angsur menjadi suatu kebiasaan tersendiri dalam administrasi negara. Tujuannya agar pelayanan kepada publik meningkat baik dari segi kualitas dan kuantitas.

Negara dalam melaksanaan kegiatan penyelenggaraan pemerintahan, dilakukan melalui lembaga-lembaga pemerintahan atau biasa dikategorikan sebagai badan hukum publik. Disebut dengan badan hukum publik karena badan hukum tersebut pendirian atau pembentukannya berdasarkan kontruksi hukum publik, lingkungan kerja yang melakukan tindakan-tindakan atau perbuatan-perbuatan publik, serta diberikan wewenang-wewenang publik seperti membuat peraturan dan keputusan. Disamping itu, lembaga pemerintahan atau badan hukum publik juga dapat melakukan tindakan-tindakan atau terlibat dalam lalu lintas perdata. Sehingga, pemerintahan dapat dilihat dari 2 (dua) sisi (twee petten), yaitu sebagai wakil dari jabatan (bestuurorgan), dan sebagai badan hukum (rechtpersoon).

Akan tetapi dalam menyikapi arus perkembangan ketatanegaraan dan kebutuhan warga negara yang semakin kompleks, sesuai dengan prinsip negara kesejahteraan (welfare state), ruang lingkup pemerintahan juga semakin berkembang. Dalam melaksanakan fungsi penyelenggaraan pemerintahan, dalam praktik dapat dilihat bahwa lembaga pemerintahan atau badan hukum publik jumlahnya cukup terbatas, terutama yang bergerak dalam lalu lintas keperdataan. Oleh sebab itu dalam praktik seringkali pemerintah membentuk sebuah badan hukum privat yang fungsinya untuk melaksanakan pemerintahan, atau pekerjaan pemerintahan tersebut diserahkan kepada badan hukum privat yang telah ada sebelumnya.

Apabila dikaji secara paradigmatik, keberadaan badan hukum baik publik atau privat memiliki syarat-syarat tersendiri yang pada akhirnya melahirkan sejumlah perbedaan antara badan hukum publik dan privat, walaupun dalam satu titik yang sama, kedua badan hukum tersebut samasama memliki kekayaan yang dipisahkan dari anggotanya. Legitimasi tentang badan hukum baik publik dan privat tersebar dalam beberapa bentuk peraturan perundang-undangan, disebabkan karena belum ada pengaturan dalam bentuk Undang-Undang tentang badan hukum secara tersendiri. Dalam realitas, terdapat suatu badan hukum yang perbuatannya adalah privat, tetapi dibentuk berdasarkan hukum publik. Ada pula badan hukum publik, tetapi perbuatannya ialah 
privat, dan sebaliknya, meski bentuknya ialah badan hukum privat, tetapi sifatnya melakukan perbuatan publik.

Mengenai badan hukum privat yang fungsinya melaksanakan penyelenggaraan pemerintahan memilik konsekuensi tersendiri dari segi ketatanegaraan dan administrasi negara. Misalnya, mengenai apakah suatu keputusan dari badan hukum privat yang menyelenggarakan fungsi pemerintahan dan merugikan warga negara dapat disengketakan di pengadilan tata usaha negara. Sebaliknya, apakah keputusan dari organ pemerintahan di bidang keperdataan dapat disengketakan di pengadilan perdata, mengingat tindakan pemerintah dalam kaidah adminitrasi negara selalu bersegi satu, dalam arti, tidak berdasarkan persesuaian kehendak dalam kaidah perdata. Masalah ini cukup menarik apabila ditinjau dari sudut asas dan teori hukum, terutama hubungannya dengan kaidah ketatanegaraan dan administrasi negara, maupun kaidah Perdata.

\section{PEMBAHASAN}

\section{Tinjauan Umum Perihal Badan Hukum dari Sudut Ketatanegaraan}

Dalam kaidah hukum, khususnya hukum perdata, penyandang hak dan kewajiban (de drager van de rechten en plichten) selain manusia sebagai natuurlijkpersoon, terdapat pula badan hukum sebagai rechtspersoon. Badan hukum adalah suatu badan yang disamping manusia perorangan juga dianggap dapat bertindak dalam hukum dan yang mempunyai hak-hak, kewajiban-kewajiban dan perhubungan hukum terhadap orang lain atau badan lain (Wirjono Prodjodikoro, 1992 : 23). Badan hukum adalah kumpulan dari orang-orang yang bersama-sama mendirikan suatu badan (perhimpunan) dan kumpulan harta kekayaan, yang tersendiri untuk tujuan tertentu (yayasan), baik perhimpunan maupun yayasan keduanya berstatus sebagai badan hukum, jadi merupakan persoon, pendukung hak dan kewajiban (Sri Soedewi Masjchoen sofwan, 1964 : 29).

Badan hukum terdiri dari badan hukum publik (publiek rechtspersoon) dan badan hukum privat (privaat rechtspersoon). Badan hukum publik adalah badan hukum yang didirikan oleh negara untuk kepentingan publik atau negara, dan diatur dalam perundang-undangan, misalnya negara, pemerintah daerah, Bank Sentral, BUMN, dan sebagainya. Sedangkan badan hukum privat adalah badan hukum yang didirikan untuk kepentingan individu dengan tujuan tertentu dan sesuai hukum yang berlaku secara sah, mislanya Perseroan Terbatas, Firma, Persekutuan Komanditer, Perbankan, Koperasi, Partai Politik, Ormas, Yayasan, dan sebagainya (P.N.H Simanjuntak, 2015 $: 29)$. 
Senada dengan itu, menurut C.S.T Kansil dan Cristine S.T Kansil (2002: 10-13), badan hukum publik adalah badan hukum yang didirikan berdasarkan hukum publik atau yang menyangkut kepentingan publik atau orang banyak atau negara umumnya. Sedangkan badan hukum privat adalah badan hukum yang didirikan berdasarkan hukum sipil atau perdata yang menyangkut kepentingan pribadi orang dalam badan hukum tersebut. Badan hukum privat merupakan badan swasta yang didirikan oleh orang pribadi untuk tujuan tertentu seperti, mencari keuntungan, pendidikan, sosial, politik, kebudayaan, dan sebagainya, menurut hukum yang berlaku secara sah.

Pembagian antara badan hukum publik dan privat secara kategoris memang relevan dalam kaidah keperdataan. Akan tetapi, sebagaimana telah disinggung sebelumnya bahwa dalam kehidupan sehari-hari tidak selalu didasarkan pada pembagian tersebut. Dalam kenyataannya terdapat sebuah badan hukum privat yang melakukan tindakan-tindakan publik, sebaliknya, ada pula badan hukum publik yang melakukan tindakan-tindakan keperdataan. Lebih konkret lagi, pemerintah yang pada dasarnya berkedudukan sebagai organ pemerintahan (bestuurorgan), juga berkedudukan sebagai badan hukum (rechtspersoon). Dalam pada itu, tindakan pemerintahan selalu atas dan atau dengan nama pemerintah ketika melakukan tindakan atau perbuatan hukum baik dari segi publik maupun privat.

Kenyataan dalam kehidupan sehari-hari menunjukan bahwa dewasa ini tidak mudah untuk mengualifikasikan suatu badan hukum, apakah suatu badan hukum itu adalah badan hukum publik atau privat dari segi konseptual. Misalnya uraian dari Simanjuntak dan duo Kansil diatas yang memasukan Partai Politik sebagai badan hukum privat, padahal dalam kenyataannya Partai politik lebih cenderung bergerak dalam bidang publik, yakni dengan tujuan merebut kekuasaan negara. Ataupun juga misalnya kedudukan Perguruan Tinggi Negeri yang dibentuk berdasarkan Peraturan Pemerintah Nomor 61 tahun 1999, sebagai badan hukum privat. Begitu pula dengan BUMN yang dianggap merupakan badan hukum publik, akan tetapi perbuatan hukumnya merupakan perbuatan privat.

Disamping itu, apabila kualifikasi pembentukan atau pendirian suatu badan hukum ditentukan hanya dari subyek hukum yang membentuknya yakni dibentuk oleh kekuasaan umum negara atau perseorangan, ataupun berdasarkan peraturan hukum tertentu baik peraturan perundang-undangan atau menurut hukum yang berlaku secara sah, jika dilihat dari persfektif 'wet in matrielle zin' maka aturan ataupun dasar hukum yang mengatur tentang pembentukan atau 
pendirian badan hukum, semuanya disebut dengan peraturan perundang-undangan. Artinya, seluruh badan hukum yang eksis di Indonesia keberadaannya berasal dari atribusi maupun delegasi peraturan perundang-undangan.

Kenyataan ini pada akhirnya membuat konsep antara badan hukum publik dan privat tidak lagi cukup hanya dengan berdasarkan pengertian-pengertian primer tentang badan hukum. Menurut Soenawar Soekowati (www.saplaw.top), badan hukum yang didirikan dengan konstruksi hukum publik, belum tentu merupakan badan hukum publik dan juga belum tentu mempunyai wewenang publik. Sebaliknya juga, badan hukum yang didirikan oleh orang-orang swasta, namun dalam stelsel hukum tertentu badan tersebut mempunyai kewenangan publik.

Di Indonesia, untuk menentukan perbedaan antara badan hukum publik dan badan hukum perdata, digunakan dari gabungan pendapat dari de heersende' leer dan para sarjana Jerman, untuk saling melengkapi serta ketentuan dalam Pasal 1653 KUHPerdata. Jadi untuk dapat memecahkan masalah tersebut, dalam stelsel hukum Indonesia digunakan kriteria, yaitu ; (1) dilihat dari cara pendiriannya atau terjadinya, artinya badan hukum itu diadakan dengan konstruksi hukum publik yaitu didirikan oleh penguasa dengan undang-undang atau peraturan-peraturan lainnya; (a) lingkungan kerjanya, yaitu apakah dalam melaksanakan tugasnya badan hukum itu pada umumnya dengan publik atau umum melakukan perbuatan-perbuatan hukum perdata, artinya bertindak dengan kedudukan yang sama dengan publik atau tidak. Jika tidak, maka badan hukum itu merupakan badan hukum publik; (b) Mengenai wewenangnya, yaitu apakah badan hukum yang didirikan oleh penguasa itu diberi wewenang untuk membuat keputusan, ketetapan atau peraturan yang mengikat umum. Jika ada wewenang publik, maka ia adalah badan hukum publik.

Lebih lanjut dikatakan bahwa, jika ketiga kriteria diatas terdapat pada suatu badan atau badan hukum, maka dapat disebut badan politik (www.saplaw.top, Ibid).

Menurut Jimly Asshiddiqie (2010 : 74-75), kebutuhan untuk membedakan antara badan hukum publik dan privat merupakan pemikran praktis di kalangan ahli hukum perdata saja. Sebab dari persfektif hukum tata negara dan administrasi negara, pembedaan antara keduanya tidak banyak membawa manfaat sebab badan hukum publik bagi sarjana hukum tata negara adalah lembaga-lembaga negara yang tentunya merupakan subyek hukum tersendiri. Lebih lanjut menurut Jimly Asshidiqqie, semua organ pemerintahan adalah juga badan hukum yang bersifat, dan karenanya, dapat menyandang hak dan kewajiban yang terpisah dari anggotanya. Oleh sebab itu sebutan untuk lembaga negara (state institutions, state agencies, atau state organs), terhadap 
status hukum kelembagaan yang bersangkutan sudah terselesaikan dengan sendirinya. Sehingga tidak perlu dipersoalkan apakah lembaga-lembaga negara tersebut adalah badan hukum atau bukan, terlebih lagi mempersoalkan statusnya apakah badan hukum publik ataupun privat.

\section{Badan Hukum Privat dalam Penyelenggaraan Pemerintahan}

Terlepas dari diskursus teoritis tentang perbedaan antara badan hukum publik dan privat, kenyataannya badan hukum privat juga terlibat dalam praktik penyelenggaraan pemerintahan. Walaupun dalam beberapa Undang-Undang, salah satunya Undang-Undang No. 30 tahun 2014 tentang Administrasi Negara hampir tidak menyebutkan secara tegas tentang kedudukan badan hukum privat dalam penyelenggaraan pemerintahan. Akan tetapi dalam Pasal 1 angka 19 dan 20 Undang-Undang Nomor 30 tahun 2014 mengenai Izin dan Konsesi, hal ini jelas memperlihatkan adanya suatu legitimasi kepada badan hukum privat untuk terlibat dalam penyelenggaraan pemerintahan.

Dalam kegiatan administrasi negara atau pemerintahan, pelaksanaan tugas-tugas pemerintahan dalam kenyataannya tidak hanya dijalankan oleh suatu jabatan pemerintahan yang telah dikenal secara konvensional, tetapi juga oleh badan-badan swasta. Hal ini sebagaimana diuraikan oleh Philipus M. Hadjon, et.al, (2008 : 70-71), bahwa oleh karena wewenang publik hanya dimiliki oleh "penguasa", maka setiap orang maupun badan yang memiliki hukum publik harus dimasukan sesuai definisinya. Dengan kata lain, setiap orang atau badan yang memiliki wewenang publik meski tidak termasuk dalam daftar nomenklatur Konstitusi ataupun peraturan perundang-undangan, baik pusat maupun daerah, harus dimasukkan dalam desentralisasi (fungsional).

Apa yang diuraikan oleh Hadjon, et.al, tersebut diatas menarik sebab setiap badan hukum

yang terlibat dalam penyelenggaraan pemerintahan, harus dikategorikan sebagai badan hukum publik meski bukan dalam pengertian berkedudukan sebagai lembaga negara. Akan tetapi dalam kenyataannya eksistensi suatu badan hukum (bukan mengenai tindakan hukum dari suatu badan hukum), apakah dikategorikan sebagai badan hukum publik atau privat secara paradigmatik masih dapat dipersoalkan. Misalnya mengenai BUMN yang selama ini status BUMN adalah Persero sehingga secara otomatis diatur dan dikuasai berdasarkan hukum privat, walaupun pengaturan ataupun pendiriannya didasarkan pada hukum publik.

Dalam pada itu, banyak kalangan yang berpendapat, misalnya Arifin P. Soeria Atmadja (dalam Ridwan HR, 2014 : 84), yang mengatakan bahwa BUMN pada hakikatnya adalah badan 
hukum privat, meski diatur berdasarkan hukum publik. Alasan yang mendasari sekurangkurangnya ada 2 (dua) hal. Pertama, kekayaan negara yang menjadi modal dari badan usaha tersebut telah berubah statusnya menjadi kekayaan badan usaha tersebut, meskipun saham badan usaha tersebut $100 \%$ milik negara. Kedua, kedudukan pejabat pemerintah yang duduk sebagai komisaris setara dengan pemegang saham lainnya, sehingga imunitas publiknya sudah tidak berlaku lagi.

Menurut Aminuddin Ilmar (2012:152-153), dalam kajian ilmu hukum, pembedaan badan hukum publik dan privat memang sering tidak terlalu dipermasalahkan. Pembedaan keduanya hanya digunakan sebatas untuk memperjelas kedudukan suatu kasus, yakni tujuan hukum publik adalah menyangkut kepentingan umum, sementara hukum privat menyangkut kepentingan perseorangan. Lebih lanjut menurut Aminuddin Ilmar, perbedaan seperti itu tidak menghasilkan suatu perbedaan yang jelas, sehingga masih diperlukan kriteria lain untuk membedakan kedua jenis hukum tersebut.

Apa yang diuraikan oleh Aminuddin Ilmar bukan tanpa alasan, sebab salah satu kriteria utama dari badan hukum publik yang dimaknai sebagai lembaga negara ialah kemungkinan produk keputusan dari suatu lembaga negara dapat disengketakan dalam Pengadilan Tata Usaha Negara (PTUN). Disisi lain, lembaga negara yang bersifat badan hukum publik pun, keputusannya tidak selalu dapat disengketakan dalam peradilan administrasi meski dalam kapasitas menyelenggarakan fungsi pemerintahan negara. Apakah badan hukum privat yang menyelenggarakan fungsi pemerintahan, tindakan hukumnya atau keputusannya dapat disengketakan di PTUN ataukah tidak, masih belum menemukan satu kesatuan pendapat.

Hal ini belum lagi apabila dikaitkan dengan pesatnya perkembangan Lembaga Swadaya Masyarakat (LSM) atau Non Governmental Organizations (NGO's) yang terdiri dari unit-unit kegiatan kepentingan baik publik atau privat. Unit-unit perkumpulan tersebut ada juga yang bersifat quasi, yakni setengah publik atau setengah privat. Manakala suatu unit-unit tertentu yang pada dasarnya merupakan badan hukum privat, tetapi memiliki fungsi penyelenggaraan pemerintahan, atau sebaliknya, merupakan badan hukum publik tetapi melakukan tindakan hukum privat, maka dikategorikan sebagai quasi badan hukum publik atau privat.

Uraian diatas menunjukan bahwa terdapat perbedaan dalam melihat rechtspositie suatu badan hukum antara kajian ketatanegaraan maupun administrasi negara, dan kajian keperdataan. Dalam kajian ketatanegaraan dan administrasi negara, status suatu badan hukum tidak terlalu 
dipersoalkan. Sebab badan hukum publik identik dengan lembaga negara yang memiliki fungsi ganda (twee petten), yakni sebagai organ pemerintahan dan badan hukum. Sedangkan dalam kajian keperdataan, status mengenai badan hukum ditentukan dari beberapa syarat, salah satunya mengenai dasar pendirian dari suatu badan hukum.

Terlepas dari hal yang demikian, eksistensi badan hukum privat dalam penyelenggaraan pemerintahan di Indonesia mesti dilihat sebagai usaha administrasi negara dalam merespon perkembangan warga masyarakat, termasuk sebagai inovasi dalam mengatasi stagnansi pemerintahan. Oleh sebab itu dalam persfektif ketatanegaraan dan administrasi negara, tindakan hukum pemerintahan baik melalui badan hukum publik maupun privat mesti dilihat sebagai kerjakerja koordinatif pemerintahan. Dari sudut kepastian hukum, beberapa hal menyangkut eksistensi suatu badan hukum juga perlu ditingkatkan, misalnya dengan membentuk suatu peraturan perundang-undangan yang khusus mengatur soal badan hukum.

Pendirian ataupun pembentukan seluruh badan hukum publik maupun privat di Indonesia menurut penulis pada hakikatnya berdasarkan peraturan perundang-undangan. Sehingga tidak perlu dibedakan antara mana badan hukum yang dibentuk melalui "peraturan perundangundangan", dan mana yang dibentuk "menurut hukum yang berlaku secara sah", sebab dari segi 'wet in matrielle zin' keduanya adalah peraturan perundang-undangan. Beda halnya apabila kriteria "menurut hukum yang berlaku secara sah" ingin dikaitkan dengan salah satu bentuk hukum lainnya yakni putusan atau penetapan pengadilan, maka mesti diadakan kajian secara khusus dan mendalam.

Disisi lain, kategorisasi antara badan hukum publik dan privat yang didirikan berdasarkan peraturan perundang-undangan, apabila dikaitkan dengan Pasal 5 huruf (a) Undang-undang No. 12 tahun 2011, salah satu asas pembentukan peraturan perundangan-undangan adalah menyangkut masalah kejelasan tujuan. Artinya, pengaturan tentang kedudukan suatu badan hukum baik publik ataupun privat harus jelas dan tegas untuk menjamin kepastian hukum, tidak semata-mata hanya sebagai kebutuhan praktis manakala dibutuhkan dalam menyelesaikan sengketa yang mempertanyakan status suatu badan hukum tersebut.

\section{SIMPULAN}

Meskipun terdapat perbedaan antara kajian ketatanegaraan dan administrasi negara dengan kajian keperdataan mengenai kedudukan atau rechtspositie badan hukum privat, akan tetapi dalam 
praktik sehari-hari menunjukan bahwa badan hukum privat juga terlibat dalam proses penyelenggaraan pemerintahan. Baik badan hukum privat yang didirikan oleh pemerintah ataupun oleh swasta, juga tindakan hukum secara langsung maupun tidak langsung oleh badan hukum privat. Walaupun demikian, kajian teoritis-paradigmatis tentang eksistensi badan hukum perlu dikembangkan mengingat masih terdapat beberapa isu mendasar. Hal ini diperlukan sebab negara dalam pengertian staat in beweging (negara dalam keadaan bergerak) memiliki ruang lingkup yang sangat luas. Termasuk pula negara Indonesia, mengingat Pasal 33 ayat (2) dan (3) dalam hal hak menguasai negara yang biasanya dilakukan dengan privatisasi tidak bersifat koorporatis semata, sebab menyangkut hajat hidup orang banyak. Pembentukan peraturan perundang-undangan yang mengatur tentang badan hukum, menurut penulis sedikit banyak akan membawa dampak positif dalam ketatanegaraan dan administrasi negara Indonesia.

\section{DAFTAR PUSTAKA}

Asshiddiqie, Jimly, 2010, Perkembangan \& Konsolidasi Lembaga Negara Pasca Reformasi, Sinar Grafika, Jakarta.

Dyah Hapsari Prananingrum. 2014. Telaah Terhadap Esensi Subjek Hukum : Manusia dan Badan Hukum, Jurnal Refleksi Hukum, Vol. 8, No. 1. DOI : https://doi.org/10.24246/jrh.2014.v8.i1.p73-92.

Hadjon, Philipus M., et.al, 2008, Pengantar Hukum Administrasi : Introduction to the Indonesian Admnistrative Law, Gajah Mada University Press, Yogyakarta.

Herlin Budiono. 2012. Arah Pengaturan Undang-Undang Nomor 40 tahun 2007 tentang Perseroan Terbatas dalam Menghadapi Era Global. Jurnal Rechtsvinding Media Pembinaan Hukum Nasional. Vol. 1 No. 2.

HR, Ridwan, 2014, Hukum Administrasi Negara, PT. RajaGrafindo Persada, Jakarta.

Ilmar, Aminuddin, 2012, Hak Menguasai Negara dalam Privatisasi BUMN, Kencana Prenadia Media Group, Jakarta.

Kansil, C.S.T \& Kansil, Cristine S.T, 2002, Pokok-Pokok Badan Hukum, Pustaka Sinar Harapan, Jakarta.

Kurniawan, Luthfi J. \& Lutfi, Mustafa, 2012, Perihal Negara, Hukum \& Kebijakan Publik, Setara Press, Malang.

Marbun, SF \& MD, Mahfud, 2006, Pokok-Pokok Hukum Administrasi Negara, Liberty, Yogyakarta.

Prodjodikoro, R. Wirjono, 1992, Asas-asas Hukum Perdata, Sumur Bandung, Jakarta.

Setiawan, Yudhi, et.al, 2017, Hukum Administrasi Pemerintahan (Teori dan Praktik), PT RajaGrafindo Persada, Jakarta.

Simanjuntak, P.N.H, 2015, Hukum Perdata Indonesia, Prenadamedia Group, Jakarta.

Sofwan, Sri Soedewi Masjchoen, 1964, Hukum Badan Pribadi, Yayasan Badan Penerbit Gajah Mada, Yogyakarta.

Taufik H. Simatupang. 2013. Legalitas Subjek Hukum Yayasan Sebagai Badan Hukum (Kedudukan Yayasan yang Terbentuk Sebelum Lahirnya UU 28 tahun 2004 tentang 
Perubahan UU Nomor 16 tahun 2001 tentang Yayasan). Jurnal Ilmiah Kebijakan Hukum. Vol. 7, No. 1. 